\title{
Ігор Немчинов
}

\section{АНТИНОМІї СВОБОДИ, АБО ТРИ СПОКУСИ ДОСТОЄВСЬКОГО}

Понад століття хто тільки не намагався «скинути Достоєвського 3 корабля сучасності». Проте спадщина письменника не просто залишається в полі сучасних гуманітарних досліджень, але й досі має неабиякий евристичний потенціал.

Як на межі XIX-XX ст., так і нині, переважна більшість російських дослідників вважають Достоєвського релігійним мислителем, який щиро вірить у Бога й людину. Актуальною залишається оцінка, яку 1931 року дав Достоєвському Георгій Флоровський: «Ніколи для нього не закривався образ Божий у людині. Не закривався тому, що всюди його відкривала любов. Ця любов зберегала Достоєвського від песимізму. Вона зберегала його від переляку та страху. Він вірив через любов, а не черех страх. Перед духовним поглядом Достоєвського завжди стояв образ Христа. Й він свідчив про нескінченність Божої любові до людини. Неможливо людині вступати в суперечку з Богом й применшувати Божественне свідчення про людину відчаєм та сумнівом» [Флоровський, 1990: c. 390]. Якщо ж віру Достоєвського у Христа можна назвати такою, що не збігається цілковито 3 православ'ям, то й тут росіяни мають пояснення. Нетрадиційність віри мислителя виявляється в тому, що «у ній саме людина - у своїй індивідуально-особистісній, неповторній та органічній сутності - постає як носій божественого начала, як Абсолют, який визначає все, що вже існує в реальності, й зумовлює моживість перетворення всього сущого» [Евлампиев, 2012: c. 469]. На наш погляд, $з$ таким тлумаченням творчості Достоєвського важко погодитися. Останній, певна річ, хотів би не «применшувати Божественне свідчення про людину відчаєм та сумнівом», проте усвідомлював небезпеку становища, за якого людина вважає себе Абсолютом.

На Заході цікавість до тем і образів Достоєвського залишається стабільно високою. 3 найсучаснішої літератури теми нашої статті безпосередньо стосуються грунтовні дослідження Джеймса Скенлена про Достоєвського-мислителя [Scanlan, 2002] i Джозефа Франка, в якому автор розглядає творчість російського письменника в контексті його доби [Frank, 2010].

Хоча загалом західні дослідники багато у чому орієнтуються на російську традицію, нерідко з'являються доволі оригінальні спроби розглянути той чи інший аспект спадщини Достоєвського. Так, зокрема, смислове визначення спокус, якими Дух пустелі випробовує Христа в «Легенді про Великого Інквізитора»,

(C) I. Немчинов, 2013 
досліджується з літературознавчої [Natov, 1987; Jones, 1986] та теологічної [Kroeker, Ward, 2001] точок зору. Вартим уваги є намагання усвідомити позиції Достоєвського як політичного мислителя та піддати аналізу його розуміння різних вимірів свободи [Dostoevsky's Political..., 2013; Sandoz, 2000]. Безумовно, заслуговують на увагу спроби зіставлення Достоєвського з Кантом [Cherkasova, 2009], Кіркегором [Pattison, 2001], Ніцше [Hubben, 1997].

Однак, на нашу думку, автори, що звертаються до спадщини Достоєвського, намагаються розглядати той чи інший аспект його творчості як більш-менш сталу, закінчену систему.

Слідом за російською традицією, вони прагнуть зафіксувати «позитивного», правильного Достоєвського. На наш погляд, такого Достоєвського не існує, він ставив «прокляті питання» не для того, щоб отримати (чи надати іншим) відповідь на них. Він ставив їх заради самого процесу запитування, який фактично збігається з їхнім «проживанням».

Адже головною темою його творчості була свобода, поняття чи не найбільш антиномічне. Саме ця антиномічність й захоплювала Достоєвського, він постійно випробовував свободу, проводячи свого героя через сумніви, самоприниження, спокуси тощо. Сама російська мова ніби спонукала письменника раз-у-раз відтворювати антиномічність не тільки свободи, але й буття як такого. Адже «будьяка викладена цією мовою ідея в той самий час перетворюється на свою протилежність, - зазначав Йосип Бродський, - й немає для російського синтаксису заняття більш захоплюючого й спокусливого, ніж передача сумніву та самоприниження» [Бродский, 1992: с. 75].

Імануель Кант вважав, що розв'язати антиномію свободи в сфері лише інтелектуальній неможливо й пропонував зробити це через фіксацію приналежності людини одночасно двом світам: феноменальному та ноуменальному. Феноменальне в людині підкоряє іiі природній необхідності. Людина ж як трансцендентна особистість неможлива без свободи. Адже «[якщо] наша воля не вільна і душа $є$ так само подільною та тлінною, як і матерія, то моральні ідеї та засади також втрачають усю значущість і валяться разом із трансцендентальними ідеями, що творили для них теоретичну підпору», - писав німецький філософ [Кант, 2000: с. 287]. Отже, тільки шляхом реалізації права на свободу волі, за Кантом, людина втілює той моральний закон, що закладений в ній.

За Достоєвським, свобода також не є суто теоретичною проблемою, вона переживається людиною «усім єством». Він усвідомлює, що питання про свободу - 3 тих, які не мають відповіді, наданої раз й назавжди. Це - одвічне питання, «проживання» якого людиною триває протягом усього життя, й того виявляється замало. Як, власне, сталося й з самим Достоєвським...

3 одного боку, він вбачає смисл людського життя саме у свободі, яка тільки одна може вести людину шляхами моралі. 3 іншого, він яскраво та переконливо змальовує іiї руйнівний потенціал, коли вона виявляється сваволею.

Свобода в Достоєвського нерозривно пов'язана з протистоянням добра та зла. Цілком у кантівському дусі, він розрізняє «культуру виховання» (власне, культуру) та «культуру вміння» (цивілізацію). Суперечність між культурою та цивілізацією має принциповий характер. В історіософії Достоєвського воно уособлене Росією та Свропою. Цивілізація - це загибель, вмирання культури. Звідси порівняння Свропи з кладовищем. «Дорогі там лежать покійники, - каже Іван Карамазов, - кожен камінь 
над ними промовляє про таке гаряче минуле життя, про таку пристрасну віру у свій подвиг, у свою істину, у свою боротьбу та свою науку, що я, знаю наперед, впаду на землю та буду цілувати ці камені та плакати над ними, - у той же час переконаний усім серцем моїм, що все це вже давно кладовище й ніяк не більше» [Достоевский, 1991: c. 259].

Оскільки Свропа відмовилася від свого великого покликання, вона втратила свою унікальність та цінність для Бога. А це, власне, й означає смерть. Натомість, «одна Росія живе не для себе, а для думки, - каже Версілов, - й погодься, мій друже, знаменний факт, що ось уже майже століття, як Росія живе рішуче не для себе, а для однієї лише Європи! А їм? О, їм присуджені страшні муки раніше, ніж досягнуть царства Божого» [Достоевский, 1990b: с. 597]. Версілов навіть порівнює Росію 3 розіп'ятим Христом, натякаючи на їі мученичество.

На ідеї жертовності російської людини, її всесвітньому характері наголошує Достоєвський й у нарисі «Пушкін»: «Так, призначення російської людини є безумовно всеєвропейським та всесвітнім. Стати справжнім росіянином, стати сповна росіянином, можливо, й значить тільки (врешті решт, це підкресліть) стати братом всіх людей, вселюдиною, якщо бажаєте» [Достоевский, 1995а: с. 439].

Якщо Європа - це історія, що твориться людьми, котрі зневажають Божий закон, протистояння та боротьба не вщухають тут аж до катастрофічного ії кінця, то Росія історія, в якій торжествують любов та жертовність. Відтак, для Достоєвського Росія та Європа уособлюють дві моделі розвитку: від людини до Христа й від Христа - до людини. Перша - свободу, друга - необхідність.

Й тут на Достоєвського чекає перша спокуса - «російський Христос» як ототожнення російського народу та Христа...

\section{Шатов}

Христос у Шатова настільки тісно пов'язаний з ідеєю «народа-богоносця», що вони в нього майже тотожні. Шатов каже: «Мета всього руху народного, в усякому народі і в усякий період його буття, є одне тільки шукання Бога, Бога свого, неодмінно власного, й віра в нього як єдиного істинного» [Достоевский, 1990а: с. 238]. За влучним висловом Миколи Бердяєва, «Шатов почав вірити, що російський народ народ-богоносець, коли він у Бога ще не повірив» [Бердяев, 1990: с. 126]. Але чи не в цьому полягає трагедія російського православ'я? В процесі перетворення російської церкви на суто національний ідеологічний інститут вона крок за кроком втрачає універсальний дух християнства. «Коли боги стають спільними, то вмирають боги та й віра в них разом з самим народом. Чим сильніший народ, тим більш особливий його бог», - продовжує Шатов [Достоевский, 1990а: с. 238]. На зауваження Ставрогіна, що він зводить Бога до атрибуту народності, Шатов заперечує: «Навпаки, народ підношу до Бога. Та й чи було коли-небудь інакше? Народ - тіло боже. Будь-який народ до тієї пори й народ, поки має свого бога особливого, а всіх інших на світі богів виключає без будь-якого примирення; поки вірує в те, що своїм богом переможе й вижене зі світу всіх інших богів» [там же, с. 239].

Звичайно, не слід цілковито ототожнювати Івана Шатова й самого Достоєвського. Але, схоже, на запитання Ставрогіна, чи вірить він у Бога, Достоєвський, так само, як й Шатов, відповів би: «Я вірую в Росію, в їі православ’я... Я вірую в тіло Христове... Я вірую, що нове пришестя відбудеться в Росії... Я... я буду вірити в 
Бога» [там же, с. 241]. Хіба що, у відповіді Достоєвського «я буду вірити в Бога» цілком могло б трансформуватися в «я хочу вірити в Бога»...

На місці єдиного Бога опиняється бог національний, «російський бог», «російський Христос». Росія та Христос пов'язані тут так тісно, що відмова від одного тягне за собою автоматичну відмову від іншого. Шатов нагадує Ставрогіну: «Чи не ви казали мені, що якби математично довели вам, що істина поза Христом, то ви погодилися 6 краще залишитися 3 Христом, ніж 3 істиною? ${ }^{1} . . »$ [там же, с. 237].

Кидаючись, слідом за Шатовим, за примарою національного бога, Достоєвський піддається спокусі націоналізму. «В християнстві ідеї національності беззаперечно належить своє певне місце, але якщо саме християнство розуміється та тлумачиться лише з ідеї національності, а не з Христа як єдиного й живого центру, то, очевидно, ми маємо підміну: уже не народ - тіло Боже, а сама віра робиться тілом народу, писав Сергій Булгаков. - Шатов справді виявляється ідеологічним попередником тієї хворобливої течії російського життя, в якій націоналізм стає вищим за релігію, а православ'я часто-густо виявляється засобом для політики. Цей уклін був й у Достоєвського, котрий знав про нього у собі й художньо обєктивував в образі Шатова цю спокусу біса націоналізму, що прикривається релігійними одежами» [Булгаков, 2001].

Національний бог, «російський Христос», що посів місце єдиного Бога, в свою чергу, поступається місцем ідолу, котрим у «шатовському» обличчі Достоєвського є «народ-богоносець»- російський народ. Й такій вибір зовсім не веде до свободи, адже поклоніння «народу» та свобода несумісні...

\section{Кирилов}

Коли Ставрогін прийшов вночі до Олексія Кирилова запросити того стати його секундантом на дуелі, між ними відбувся діалог:

«-Хто навчить, що всі добрі, той світ скінчить.

- Хто вчив, того розіп'яли.

- Він прийде, й ім'я йому людинобог.

- Боголюдина?

- Людинобог, у цьому різниця» [Достоевский, 1990а: с. 226].

У цьому, дійсно, різниця. Людинобог - це свобода, що переходить у свавілля. «Новий Христос», на якого очікує Кирилов, це людина, що здатна своїм земним єством підмінити Бога. Кирилов абсолютизує індивідуальну земну сутність людини, надаючи цьому штучному Абсолюту право та можливість перетворення всього сущого за образом та подобою своєю. «Бог є біль страху смерті. Хто переможе біль та страх, той сам стане богом. Тоді нове життя, тоді нова людина, все нове... Тоді історію будуть ділити на дві частини: від горили до знищення бога ${ }^{2}$, й від знищення

${ }^{1}$ Примітно, що ще взимку 1854 року у листі до Н. Д. Фонвізіної Достоєвський писав: «якби хто мені довів, що Христос поза істиною, й дійсно було б, що істина поза Христом, то мені краще хотілося б залишатися з Христом, аніж з істиною» [Достоевский, 1996: с. 96]. На наш погляд, ключовим моментом тут $є$ «якби»...

${ }^{2}$ Принагідно нагадаємо, що про знищення (смерть) Бога Достоєвський вустами Кирилова заявляє десятиліттям раніше за Фридриха Ніцше. 
бога (...) до переміни землі та людини фізично. Й світ переміниться, й справи переміняться, й думки, й усі почуття» [там же, с. 112].

На цьому шляху Кирилов має підтвердити своє право на свавілля, щоб досягнути найвищого стану. «Якщо немає Бога, то я Бог, - каже він. - Тільки це одне врятує всіх людей й у наступному ж поколінні переродить людей фізично; адже в теперішньому фізичному вигляді, скільки я думав, неможна бути людині, без колишнього Бога, нияк. Я три роки шукав атрибут божества мого й знайшов: атрибут божества мого - Свавілля! Це все, чим я можу у головному пункті показати свою непокору й нову страшну свободу мою» [там же, с. 577].

Ми не можемо прийняти позицію Ігоря Євлампієва, котрий вважає, що «у вуста Кирилова Достоєвський вкладає свої найпотаємніші думки про сутність справжньої віри, справжного безсмерття й справжнього воскресіння як перетворення земного життя. При цьому свого героя Достоєвський зробив не просто “фанатиком” віри, але людиною, готовою на “доказ” цієї віри, задля розповсюдження її поміж людей повторити жертву Христа, принести в жертву всього себе» [Евлампиев, 2000: с. 152]. Нам ближче думка М. Бердяєва про те, що найчистіша людина, що відкинула Бога й забажала сама стати богом, приречена на загибель. У своєму свавіллі вона втрачає свою свободу. Кирилов менш за все $\epsilon$ вільною духом людиною. На шляхах людинобожества гине людська свобода й гине людина [див.: Бердяев, 2001].

Ti, хто йдуть шляхом свавілля (шляхом реалізації «страшної свободи»), неминуче приходять до насилля. «Я пропоную не підлість, а рай, земний рай, іншого на землі бути не може», - говорить Шигальов, попереджаючи викладення своєї системи [Достоевский, 1990а: с. 380]. Чи може бути свобода реалізована у феноменальному світі? Чи не закінчується конструювання будь-якого «досконалого» соціального ладу зізнанням Шигальова: «Виходячи з безмежної свободи, я закінчую безмежним деспотизмом. Додам, однак, що, крім цього вирішення суспільної формули, не може бути ніякого» [там же, с. 378]?..

Достоєвський розмірковує над можливістю існування такої формули взагалі. Трохи раніше вустами того ж Шигальова він називає всіх творців суспільних систем мрійниками, казкарями, дурнями, які суперечать самі собі [див.: там же]. Пізніше, в оповіданні «Сон смішної людини» (1877), Достоєвський дотепно (хоча й не без суму) глузуватиме над утопією про «ідеальний світ».

«Смішна людина» відкрила істину «минулого листопада, а саме третього листопада», - пише він [Достоевский, 1995b: с. 121]. Потрапивши вві сні до «ідеального» світу, «смішна людина» розбестила тамтешніх мешканців, й зажадала повторити шлях Христа: «Я благав їх, щоб вони розіп’яли мене на хресті, я вчив їх, як зробити хрест. Я не міг, не в силах був вбити себе сам, але я хотів прийняти від них муки, я жадав мук, жадав, щоб у цих муках пролитою була моя кров до краплі. Але вони лише сміялися наді мною» [там же, с. 136]. Прокинувшись, «смішна людина» усе ж твердо вирішила проповідувати «ідеальний» світ. Чи не так само жалюгідно виглядає спроба будь-якого проповідника «стати Христом»?..

Достоєвський не може відмовитися від ідеологічності своїх персонажів. Вони передусім ідеї (про що, можливо, й свідчить кількість самогубств у його творах, адже ідеї помирають легше за людей). Але Достоєвський розуміє, що будь-яка ідеологія є моделюванням «ідеального» суспільства, де все розписане та розраховане, де «двічі два - чотири», що є вже не життя, а початок смерті. Як зазначав 
Яків Голосовкер, Достоєвський хоче показати читачеві «не двадцять людських трупів, а тільки один труп - труп “ідеї-самогубиці”, що плаває у крові» [Голосовкер, 1963: c. 43].

Достоєвський знає, що тотальність та запрограмованість - невід’ємні риси будьякої ідеології, що будує «навмисну» державу, котра прагне контролювати всі прояви людського життя, зтерти з людини всі риси індивідуальності. Цій державі «не можна буде ані язика крадькома виставити, ані дулі в кишені показати» [Достоевский, 1989: с. 477]. Проте, Достоєвський добре усвідомлює й недолугість тлумачення свободи, як можливості хіба що «дулю в кишені показати». Й тут перед Достоєвським постає нова спокуса...

\section{Великий Інквізитор}

Свобода заснована на стражданні, на муках вибору, свобода, власне, й є сама можливість вибору. Від страждання можна було б звільнитися, але ціною втрати свободи. Вибір - це бажання, що рівною мірою народжують добро та зло. Але відсутність вибору - безсумнівне зло, тому що суперечить самій природі людини, іiі онтологічному прагненню свободи.

Полярність Христа та Великого Інквізитора зумовлена не тільки протилежністю, але й співмірністю їхніх правд, їхньою складністю та нерозривністю. «У світовій літературі немає більш страшного персонажу, ніж інквізитор у легенді Достоєвського, - писав Антанас Мацейна. - Він - не демон, для котрого зло є “природним елементом”, як у Мефістофелі Гете. Інквізитор - людина, людина, що страждає й шукає, гине заради людства й заради нього навіть вступає в остаточну боротьбу з Христом» [Мацейна, 1999: с. 111].

Обидва супротивники виходять 3 ідеї користі людству, але розуміють ії порізному. «Ми виправили подвиг твій, - каже Великий Інквізитор Христу, - й заснували його на диві, таємниці та авторитетові, й люди зраділи, що їх знову повели, як череду, й що з сердець їхніх знято нарешті такий страшний дар, що приніс їм стільки муки... О, ми переконаємо їх, що вони тоді тільки стануть вільними, коли відмовляться від волі своєї для нас й нам підкоряться" [Достоевский, 1991: с. 289]. Слушно зауважує Я. Голосовкер, що Великий Інквізитор «знає, що ніякого "плюса" (Бога) немає, а існує лише "мінус" (ніщо) й що “плюс" треба вигадати, щоб людина не загинула в істині “мінусу”» [Голосовкер, 1963: с. 76]. Й у цьому він стає співмірним Христу.

Свобода та ймовірне зло або щастя, але без свободи - в таку ситуацію ставить людство Достоєвський. Коли Василь Розанов аналізує текст «Легенди» й говорить про те, що у ній мається на увазі католицтво [див.: Розанов, 1989: с. 110], він звужує проблему. Так само, як й Д. Франк, який зазначає, що соціалізм та католицизм стали для Достоєвського втіленням спокуси Христа хлібом та земною владою [див.: Frank, 2010: p. 794]. Інквізитор уособлює не стільки католицтво чи соціалізм, скільки Людинобога в найширшому розумінні, земну силу, яка здатна вирішити за людину іiі долю, здолавши свободу для того, щоб зробити людей щасливими [див.: Достоевский, 1991: с. 283].

Зустріч Великого Інквізитора та Христа - це й $є$ своєрідний двобій Боголюдини та Людинобога. Християнин Достоєвський натякає на перемогу Христа, який мовчить й це мовчання варте Слова. Адже «істина про свободу невимовна, - як писав Бердяєв. - Легко висловити лише ідею примусу. Істіна про 
свободу розкривається лише за протилежністю ідеям Великого Інквізитора, вона яскраво світить через заперечення проти неї Великого Інквізитора» [Бердяев, 2001]. Але письменник та мислитель Достоєвський надає в розпорядження Великого Інквізитора міцні логічні аргументи та сильну волю до здійснення свого плану. Як зазначив Й. Бродський, у класицизму Достоєвський «навчився надзвичайно важливого принципу: перш ніж викласти свої доведення, хай як потужно відчуваєш ти свою правоту й навіть праведність, слід спочатку перерахувати всі аргументи протилежної сторони. Справа навіть не в тому, що в процесі перерахування доведень, що спростовуєш, можна схилитися на протилежний бік: просто таке перерахування саме по собі є процесом вельми захоплюючим. Зрештою, можна й залишитися при своїх переконаннях; однак, висвітливши всі доведення на користь Зла, постулати істинної Віри вимовляєш вже радше 3 ностальгією, ніж із завзяттям. Що, втім, теж підвищує ступінь достовірності» [Бродский, 1992: с. 76-77].

Дійсно, Достоєвський ніби й сам не може вибрати між Людинобогом та Боголюдиною. Чи не до себе він звертає слова: «Змирися, горда людино, й насамперед зламай свою гордість» [Достоевский, 1995a: с. 428]?..

I справа не тільки в письменницькій необхідності дотримуватися достовірності. На відміну від Канта, Достоєвський намагається відшукати вирішення проблеми свободи як одвічного конфлікту добра та зла в межах історії, у феноменальному світі. Втім, розуміє, що це неможливо без певних компромісів, проте до яких він сам не готовий.

Саме «поліфонічність» (не монологічність, але й не діалектичність) творів Достоєвського якнайкраще відображає його мислення, в якому протилежні виміри свободи перебувають у антиномічному стані. Як зазначав Михайло Бахтін, у світі Достоєвського марно шукати «системно-монологічну, хоча би й діалектичну, філософську завершеність, і не тому, що вона не вдалася авторові, але тому, що вона не входила до його задумів» [Бахтин, 2002: с. 40].

Протистояння Боголюдини та Людинобога, Христа та духа пустелі, що спокушає його, а разом з ним - кожну людину, за Достоєвським, триває впродовж усієї історії. Й саме це протистояння (а не остаточний переможний результат) в людській душі $є$ надзвичайно важливим та цінним для Достоєвського.

\section{СПИСОК ЛІТЕРАТУРИ}

Бахтин М. М. Проблемы поэтики Достоевского // Бахтин М. М. Собр. соч. в 7 т. Т. $6 .-$ М.: Русские словари; Языки славянских культур, 2002. - С. 6-300.

Бердяев Н. А. Миросозерцание Достоевского // Електронний ресурс. - 2001. - Режим доступу: http://www.vehi.net/berdyaev/dostoevsky/index.html

Бердяев Н. А. Русская идея // Вопросы философии. - 1990. - №2. - С. 87-154.

Бродский И. А. О Достоевском // Набережная неисцелимых: Тринадцать эссе - М.: СП «Слово», 1992. - С. 72-77.

Булгаков С. Н. Русская трагедия // Електронний ресурс. - 2001. - Режим доступу: http://www.vehi.net/bulgakov/tragediya.html

Голосовкер Я. Э. Достоевский и Кант: размышление читателя над романом «Братья Карамазовы» и трактатом Канта «Критика чистого разума». - М.: Изд-во АН СССР, 1963. $-102 \mathrm{c}$.

Достоевский Ф. М. Бесы // Собр. соч. в 15-ти тт. Т. 7. - Л.: Наука, 1990а. - С. 7-672.

Достоевский Ф. М. Братья Карамазовы. Части I-III. // Собр. соч. в 15-ти тт. Т. 9. - Л.: Наука, 1991. - C. 5-570. 
Достоевский Ф. М. Записки из подполья // Собр. соч. в 15-ти тт. Т. 4. - Л.: Наука, 1989. C. $452-550$.

Достоевский Ф. М. Письмо Н. Д. Фонвизиной (конец января - 20-е числа февраля 1854. Омск) // Собр. соч. в 15-ти тт. Т. 15. - СПб.: Наука, 1996. - С. 95-98.

Достоевский Ф. М. Подросток // Собр. соч. в 15-ти тт. Т. 8. - Л.: Наука, 1990b. - С. 139-692.

Достоевский Ф. М. Пушкин // Собр. соч. в 15-ти тт. Т. 14. - СПб.: Наука, 1995а. C. $425-440$.

Достоевский Ф. М. Сон смешного человека // Собр. соч. в 15-ти тт. Т. 14. - СПб.: Наука, 1995b. - С. $120-137$.

Евлампиев И. И. История русской метафизики в XIX-XX веках. Русская философия в поисках абсолюта. Часть I. - СПб.: Алетейя, 2000. - 415 с.

Евлампиев И. И. Философия человека в творчестве Ф. Достоевского (От ранних произведений к «Братьям Карамазовым»). - СПб.: Изд-во РХГА, 2012. - 585 с.

Кант I. Критика чистого розуму / Переклад з німецької та примітки Ігоря Бурковського. К.: Юніверс, 2000. - 504 с.

Мацейна А. Великий Инквизитор. - Спб.: Алетейя, 1999. - 384 с.

Розанов В. В. Легенда о Великом инквизиторе Ф. М. Достоевского. Опыт критического комментария // Розанов В. В. Мысли о литературе. - М.: Современник, 1989. - С. 41157.

Флоровский Г. В. Религиозные темы Достоевского // О Достоевском. Творчество Достоевского в русской мысли 1881-1931 годов - М.: Книга, 1990. - С. 386-390.

Cherkasova E. Dostoevsky and Kant: Dialogues on Ethics. - Amsterdam \& New York: Rodopi, 2009. - XIV, 128 pp.

Dostoevsky's Political Thought / Ed. Richard Avramenko Lee Trepanier. - Lanham: Lexington Books, 2013. $-260 \mathrm{p}$.

Frank J. Dostoevsky: a writer in his time. - Princeton: Princeton University Press, 2010. - 984 p.

Hubben $W$. Dostoevsky, Kierkegard, Nietzsche and Kafka. - Scribner Book Company, 1997. $192 \mathrm{p}$.

Jones M.V. The Legend of the Grand Inquisitor: The Suppression of the Second Temptation and Dialogue with God // Dostoevsky Studies. - Toronto. - 1986. - № 7. - P. 123-134.

Kroeker P.T., Ward B.K. Remembering the End. Dostoevsky as Prophet to Modernity. - Westview Press, 2001. - xii, 280 p.

Natov N. The Ethical and Structural Significance of the Three Temptations in The Brothers Karamazov // Dostoevsky Studies. - Toronto. - 1987. - № 8. - P. 3-44.

Pattison G. Freedom's dangerous dialogue: reading Dostoevsky and Kierkegaard together // Dostoevsky and the Christian Tradition / Ed. Pattison G. \& Thompson D.O. - Cambridge, etc.: Cambridge UP, 2001. - P. 237-256.

Sandoz E. Political Apocalypse, A Study of Dostoevsky's Grand Inquisitor, 2nd ed. - Willmington, Del.: Intercollegiate Studies Institute, 2000. - 357 p.

Scanlan J.P. Dostoevsky the Thinker. - Ithaca \& London: Cornell UP, 2002. - 251 p.

Стаття одержана редакцією 14.06.2013

\section{Ihor Nemchynov}

\section{The Antinomies of the Freedom, or the Three Temptations of Dostoevsky}

In this article the main theme of Dostoevsky - the freedom is analyzed. Researchers, who study the legacy of Dostoevsky, try to consider one or another aspect of his work as a more or less constant, complete system. Following the Russian tradition, they seek to record a "positive" Dostoevsky. The author believes that there is no such Dostoevsky. Dostoevsky put 
"cursed questions" not to get a final answer to them but merely for the process of questioning what actually means "living" them through. The author believes that the antinomy of freedom for Dostoevsky leaves open the problem of choosing between the Boholyudyna and Lyudynoboh. The content of his works is studying their opposition within the human soul, which lasts throughout life. The process of choice, the arguments in favor of one or the other are more important for Dostoevsky than the final answer.

Ihor Nemchynov, Doctor of sciences in philosophy, Professor, professor at the Department of Philosophy, National Pedagogical Dragomanov University

Ігор Немчинов, доктор філософських наук, професор, професор кафедри філософії Наиіонального педагогічного університету імені М.П. Драгоманова

Игорь Немчинов, доктор философских наук, профессор, профессор кафедры философии Наиионального педагогического университета имени М.П. Драгоманова 